\title{
Identification of a control region for expression of the forespore-specific Bacillus subtilis locus spoVA
}

\author{
Brian Moldover, $\nmid$ Linhai Caoł and Patrick J. Piggot \\ Author for correspondence: Patrick J. Piggot. Tel: +1 215707 7927. Fax: +1 2157077788.
}

Department of Microbiology and Immunology, Temple University School of

Medicine, Philadelphia, PA 19140, USA

\begin{abstract}
The role of a 20 bp conserved region located 45-64 nucleotides $5^{\prime}$ of the spoVA transcription start point in Bacillus subtilis and Bacillus licheniformis was investigated by deletion analysis and by mobility shift assay. Deletions 5 ' of this conserved sequence had little effect on expression of a spoVA-lacz fusion, whereas deletions extending into the sequence reduced expression of the spoVA-lacz fusion by $85 \%$. The timing of expression of spoVA was not affected by deletion of the sequence. The region was shown by mobility shift assays to bind specifically to a protein. Binding activity was detected in protein extracts prepared from bacteria $1 \mathrm{~h}$ or more after they had started to sporulate, but not in extracts prepared from vegetative bacteria. Mutations in all known spoO loci were screened but none prevented appearance of the binding activity; nor did mutations in any of the stage II and III loci tested. It is concluded that the 20 bp conserved region is the binding site of an activator that is subject to temporal regulation independent of known spo loci.
\end{abstract}

Keywords: Bacillus subtilis, spore formation, spoV $A$ locus, transcription

\section{INTRODUCTION}

Spore formation in Bacillus subtilis is a primitive system of cellular differentiation. Under conditions of nutrient depletion, B. subtilis stops growing exponentially and enters the developmentally regulated process of spore formation. The resultant spore is dormant and is resistant to heat, organic solvents and UV damage. The process requires the precise interaction of genes and their products in both a temporal and spatial fashion. spoV $A$ is one of approximately 50 genetic loci in $B$. subtilis involved in sporulation (Hranueli et al., 1974; Piggot \& Coote, 1976; Stragier, 1994). The focus of this work is to study how spol $A$ is regulated.

Mutations in spo $V A$ result in defective spores which are sensitive to chloroform and heat (Piggot \& Coote, 1976). spol $A$ was the first spo locus whose expression could be assigned to the forespore (de Lencastre \& Piggot, 1979). The spo $V A$ locus is a large polycistronic operon encoding five or six putative proteins of unknown function (Fort \& Errington, 1985; Errington, 1993). It is located im-

\footnotetext{
+Present address: Central Research and Development, DuPont Experimental Station, Wilmington, DE 19880, USA.

$\ddagger$ Present address: Department of Pathology, Memorial Sloane-Kettering Cancer Center, New York, NY 10021, USA.
}

mediately downstream of $\operatorname{spoII} A$ and lies in a separate transcriptional unit (Fort \& Piggot, 1984; Piggot et al., 1984; Fort \& Errington, 1985). Through primer extension analysis and through the use of spoV $A-l a c Z$ fusions, transcription has been shown to begin about $3 \mathrm{~h}$ after the start of sporulation $\left(\mathrm{T}_{3}\right)$ (Errington \& Mandelstam, 1986; Moldover et al., 1991). RNA polymerase holoenzyme containing $\sigma^{\mathrm{G}}$ has been shown to transcribe spo $V A$ both in vitro and in vivo, suggesting that the spo $V A$ locus is regulated at least in part by the temporal and spatial activity of $\sigma^{\mathrm{G}}$ (Nicholson $e t$ al., 1989; Moldover et al., 1991). The timing of transcription is similar to that of other genes transcribed by $\sigma^{\mathrm{G}}$ (Errington \& Mandelstam, 1986; Nakatani et al., 1989; Nicholson et al., 1989).

The region upstream of the spoV $A$ coding sequence of Bacillus licheniformis has also been cloned and sequenced. It contains -10 and -35 promoter sequences identical to those of $B$. subtilis; these conform to the $\sigma^{\mathrm{G}}$ consensus (Moldover et al., 1991). Control of gene expression is likely to be similar in both species, with $\mathrm{E}-\sigma^{\mathrm{G}}$ regulating at least one level of expression. There is little conservation of sequence in the $17 \mathrm{bp}$ spacer region between the -10 and -35 regions, suggesting that this region is not important for control of spo $V A$. There is a region of $20 \mathrm{bp}$ extending from -45 to -64 which is perfectly conserved between the two species (Moldover et al., 1991) 
and is well conserved (17 out of $20 \mathrm{bp}$ ) in Bacililus megaterium (Tao et al., 1992). In this work, the role in spoV $A$ regulation of this upstream conserved region is explored.

\section{METHODS}

Strains. The Escherichia coli strain used was $\mathrm{DH} 5 \alpha\left[\mathrm{F}^{-}\right.$end $A 1$ bsdR 17 $\left(\mathrm{r}_{\mathrm{k}}^{-} \mathrm{m}_{\mathrm{k}}^{-}\right)$supE44 thi-1 rec $A 1$ gyr $A 96$ relA1 $\Delta(\operatorname{lac} Z Y A$-argF $)$

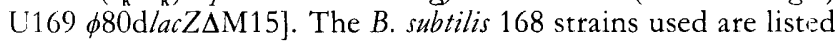
in Table 1. Antibiotics were added at the following concentrations, as needed: for $E$. coli, ampicillin $\left(100 \mu \mathrm{g} \mathrm{ml}^{-5}\right)$; for $B$. subtilis, chloramphenicol $\left(3 \mu \mathrm{g} \mathrm{ml}^{-1}\right)$ and erythromycin $\left(1 \mu \mathrm{g} \mathrm{ml} \mathrm{m}^{-1}\right)$.

Plasmids. Plasmids were maintained in E. coli $\mathrm{DH} 5 \alpha$ unless otherwise stated. Preparation of plasmids from E. coli was according to the method of Birnboim \& Doly (1979), and for small-scale preparations, by the method of Ish-Horowicz ix Burke (1981). Plasmid pPP170 was constructed by inserting a 2250 bp PstI fragment from pPP33 (Piggot et al., 1984) into the Pst I site of pBluescript II SK ${ }^{+}$(Stratagene). The Pst I fragmert extends from -92 to +2158 relative to the start site for transcription of spoVA (Moldover et al., 1991). This plasmid contained a unique $S m a I$ site at -95 relative to the spoV $\angle 1$ transcription start site, and a unique HindIII site at +2172 .

Deletion analysis. For creating nested deletions of DNA the Erase-a-Base System (Promega) based on the method of Henikoff (1984) was used. Plasmid pPP170 containing the region of interest was linearized with $S \mathrm{maI}$ and subjected to digestion with exonuclease III for varying times. The reaction: were terminated and ends made flush by $\mathrm{S} 1$ nuclease digestior: followed by treatment with Klenow fragment of DNA poly. merase. This material was digested with HindIII and ligated intc pGV34 (Youngman et al., 1989) previously digested with Smal and HindIII. The extent of the spo $V A$ promoter region was determined by dideoxy sequencing (Sanger et al., 1977).

Manipulation of phage SP $\boldsymbol{\beta}$. The phage SP $\beta$ derivative used was SP $\beta_{\mathrm{C} 2} \Delta 2:: \operatorname{Tn} 917::$ pSK10 $\Delta 6$ (Zuber \& Losick, 1987). The temperature-inducible prophage was contained in strain ZB307. Plasmid pGV34 (Youngman et al., 1989) was used to construct transcriptional fusions to $l a c Z$, and then to transfer the fusions into the SP $\beta$ derivative for further study. Manipulations of the SP $\beta$-containing strains were performed according to the methods of Zuber \& Losick (1987).

Isolation of protein. Cultures of $B$. subtilis were grown in $100 \mathrm{ml}$ MSSM (modified Schaeffer's sporulation medium; Piggot \& Curtis, 1987) and the cells harvested at the time of interest. Protein was extracted using the method described by

Table 1. B. subtilis strains used

\begin{tabular}{|ll|}
\hline Strain & Genotype \\
\hline MB24 & trpC2 metC3 rif-2 \\
SL493 & spoOJ93 metC3 rif-2 trpC2 \\
SL513 & spoOH17 trpC2 rif-2 \\
SL566 & spoOA34 phe-12 rif-2 tal-1 \\
SL741 & spoOK141 trpC2 \\
SL964 & spoOB136 metC3 tal-1 \\
SL965 & spoOF221 metC3 tal-1 \\
ZB307 & SP $\beta_{\mathrm{C} 2} \Delta 2:$ Tn917:: $\mathrm{pSK} 10 \Delta 6$ \\
\hline
\end{tabular}

Fouet $e t$ al. (1990). The pellets were washed with $10 \mathrm{ml}$ of a buffer containing $20 \mathrm{mM}$ Tris $/ \mathrm{HCl}(\mathrm{pH} 8.0), 50 \mathrm{mM} \mathrm{NaCl}$, $0.5 \mathrm{mM}$ EDTA ( $\mathrm{pH} 8.0$ ), $1 \mathrm{mM}$ DTT, $5 \%$ (v/v) glycerol, and resuspended in $10 \mathrm{ml}$ of the same buffer freshly supplemented with PMSF $\left(360 \mu \mathrm{g} \mathrm{ml}^{-1}\right)$. The mixture was then sonicated for $3 \mathrm{~min}$ ( $15 \mathrm{~s}$ on, $15 \mathrm{~s}$ off; total $3 \mathrm{~min}$ actual sonication) while being cooled with ice water. The debris was removed by centrifugation at $12000 \mathrm{~g}$ for $15 \mathrm{~min}$ at $4{ }^{\circ} \mathrm{C}$. The protein concentration in the supernatant was determined using a BioRad Protein Assay Kit and the supernatants were stored at $-70{ }^{\circ} \mathrm{C}$.

Mobility shift assay (Fried \& Crothers, 1981). This assay was performed as described by Ausubel et al. (1990), with modification. DNA fragments and synthetic oligonucleotides were labelled at the $5^{\prime}$ ends by incubation with $\mathrm{T} 4$ polynucleotide kinase in the presence of $\left[\gamma_{-}{ }^{32} \mathrm{P}\right] \mathrm{ATP}$ at $37^{\circ} \mathrm{C}$ for $60 \mathrm{~min}$. Protein $(15 \mu \mathrm{g})$ and radiolabelled probe DNA $(10 \mathrm{ng})$ were mixed in a final volume of $40 \mu \mathrm{l}$ buffer $(20 \mathrm{mM}$ Tris/ $\mathrm{HCl}, \mathrm{pH} 7 \cdot 6,50 \mathrm{mM}$ $\mathrm{NaCl}, 5 \mathrm{mM} \mathrm{MgCl}_{2}, 1 \mathrm{mM}$ DTT, $5 \%$ glycerol). The reactions were allowed to incubate at $30^{\circ} \mathrm{C}$ for $15 \mathrm{~min}$. DNA loading buffer $(2 \mu \mathrm{l})$ was added $(50 \%$ glycerol, $0 \cdot 001 \%$ bromophenol blue), and the samples were loaded onto a $4 \%$ polyacrylamide (401 acrylamide/bisacrylamide) gel. The buffer was Tris/ $\mathrm{HCl} /$ glycine, and the gel was electrophoresed at $25 \mathrm{~mA}$ constant current for $2 \mathrm{~h}$ at $4{ }^{\circ} \mathrm{C}$. The gel was transferred to Whatman paper, dried, and autoradiographed.

The oligonucleotides used were 5' GTGGTAATTTATGGTCTTTT $3^{\prime}$ and $5^{\prime}$ AAAAGACCATAAATTACCAC $3^{\prime}$.

Copy number determination. The number of tandem repeats of pPP153 in the chromosome was determined essentially as described by Piggot \& Curtis (1987). Bacteria from part of the culture used for determination of $\beta$-galactosidase activity during sporulation were harvested and embedded in agarose beads. DNA was prepared from the embedded bacteria and digested with a restriction endonuclease that cut near, but not in, the reiterated region. The size of the restriction fragment flanking the insert was determined by Southern blotting of restricted DNA that had been fractionated by pulsed-field gel electrophoresis. DNA was also digested with endonucleases that cut within the reiterated region, and examined to ensure that rearrangements had not occurred in the reiterated region. Only cultures that yielded a single predominant copy number were used for $\beta$-galactosidase assays.

Other methods were as described by Wu et al. (1989).

\section{RESULTS}

\section{Deletion analysis of the region $5^{\prime}$ to the spoVA operon}

Analysis of the region $5^{\prime}$ to $s p o V A$ employing integrative plasmids had indicated that the region extending to the Pst I site located 92 bp upstream of the spoVA transcriptional start site (i.e. at -92) was sufficient for efficient expression of spoVA (Moldover et al., 1991). To test the hypothesis that the conserved region 45-64 nucleotides upstream of the spoVA transcription start site is important for transcription, a series of nested deletions was constructed. Deletions were generated from the PstI site at -92 . Truncated fragments of the $\operatorname{spo} V A$ promoter region were fused in the correct orientation to $l a c Z$ in pGV34. The promoter-lac $Z$ fusions were then introduced into the SP $\beta$ prophage of $B$. subtilis strain ZB307 using the 


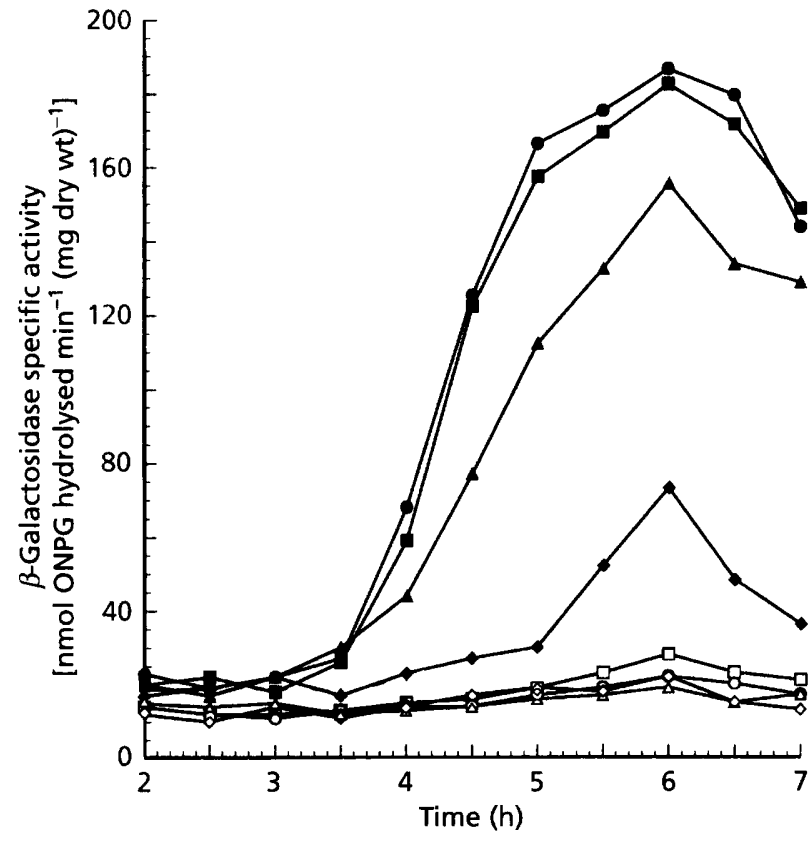

Fig. 1. Effect of deletions into the region $5^{\prime}$ to spoVA on expression of spoVA. Transcriptional fusions of different extents of the 5 region to $\operatorname{lac} Z$ were integrated into the chromosome of $B$. subtilis strain MB24 at SP $\beta$. The extent of the $5^{\prime}$ region is indicated as the distance in bp to the deletion from the transcription start point of spovA. The start of sporulation is defined as the end of exponential growth. $\square,-92 ; 0,-76$; $\Delta,-69 ; \diamond,-64 ; \square,-57 ; 0,-42 ; \triangle,-23 ; \diamond$, strain MB24 containing no lacZ fusion.

method of Zuber \& Losick (1987). The strains were assayed for $\beta$-galactosidase production during sporulation.

A deletion that removed the region further than $76 \mathrm{bp}$ upstream of the spoV $A$ transcription start (i.e. a deletion to -76$)$ gave essentially the same $\beta$-galactosidase activity as a deletion to -92 (Fig. 1). A deletion to -69 resulted in a slight decrease in $\beta$-galactosidase expression. A deletion to $-64 \mathrm{bp}$, which changes one nucleotide at the $5^{\prime}$ end of the upstream homologous region [hereafter referred to as the 'spo $V A$ box' (Fig. 2)], resulted in $41 \%$ of the $\beta$-galactosidase expression compared to the peak expression obtained with the -92 deletion. Deletions extending to $-57 \mathrm{bp}$ and $-42 \mathrm{bp}$ each reduced activity almost to the background level of endogenous activity displayed by the parent strain MB24, which contained no lac $Z$ fusion. Further deletion to $-23 \mathrm{bp}$, which lies within the promoter for $\operatorname{spo} V A$, reduced activity to that background level. It is concluded that the $\operatorname{spo} V A$ box is required for efficient expression of spoV $A$.

Southern analysis of the B. subtilis chromosome was performed using an oligomer complimentary to the spoV $A$ box to determine whether similar regions existed elsewhere on the $B$. subtilis chromosome. Southern analysis was performed at very low stringency, yet failed to detect homology with sequences other than that contained immediately upstream of $\operatorname{spoVA}$ (data not shown). This does not rule out the possibility of other homologous sequences, but if they exist they were not detected.

\section{Gel retardation analysis}

It was of great interest to determine the nature of the regulatory moiety acting on the spoVA box. The possibility that this moiety was a DNA-binding protein was explored through the use of mobility shift assays (Fried \& Crothers, 1981). A 310 bp DNA fragment extending from the $A v a \mathrm{I}$ site at -181 to the PvuII site at +129 with respect to the transcription start point for spo $V A$ was used as a probe to see if a specific protein was able to bind to the region. Protein was prepared from cultures of $B$. subtilis during growth and sporulation, and used in this assay.

A retarded band corresponding to a DNA-protein complex was detected at $1 \mathrm{~h}$ and increased in intensity up to $5 \mathrm{~h}$ after the start of sporulation (Fig. 3). The band was not detected in vegetatively growing cells, or at $0 \mathrm{~h}$. Repetition of the above experiments using the synthetic double-stranded oligomer as labelled probe showed the same temporal pattern of appearance of retarding activity (data not shown); a 50-fold molar excess of unlabelled oligomer largely prevented appearance of the retarded band, whereas 50 -fold molar excess of an unrelated oligomer did not. This indicates that the binding activity was specific for the spoV $A$ box. The binding moiety was found to be in the cell supernatant fraction $(100000 \mathrm{~g}$, $30 \mathrm{~min}$ ); it was sensitive to heat, to protease treatment and to EDTA, and is presumed to be a protein.

The dependence pattern of the DNA-protein complex was explored using protein prepared from various mutant strains of B. subtilis. As the appearance of the DNA-

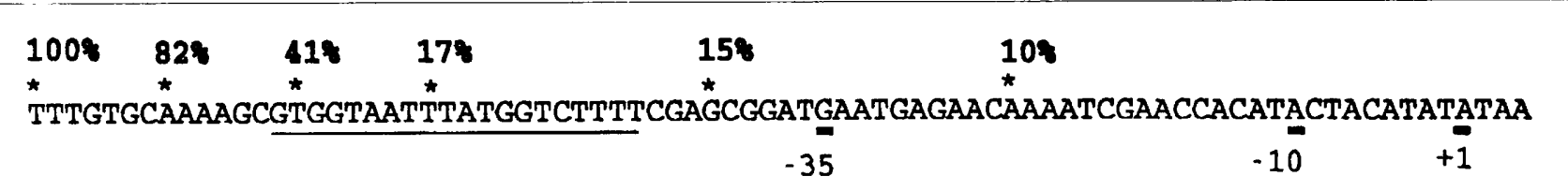

Fig. 2. Location of deletion end-points on the DNA sequence of the non-transcribed strand of the spoVA promoter region. The transcription start-point is shown as +1 . The positions of deletions used are indicated with an asterisk, and $\beta$ galactosidase activities associated with the deletions (Fig. 1) are given as a percentage of the maximum obtained with the -92 deletion. The spovA box is underlined. 


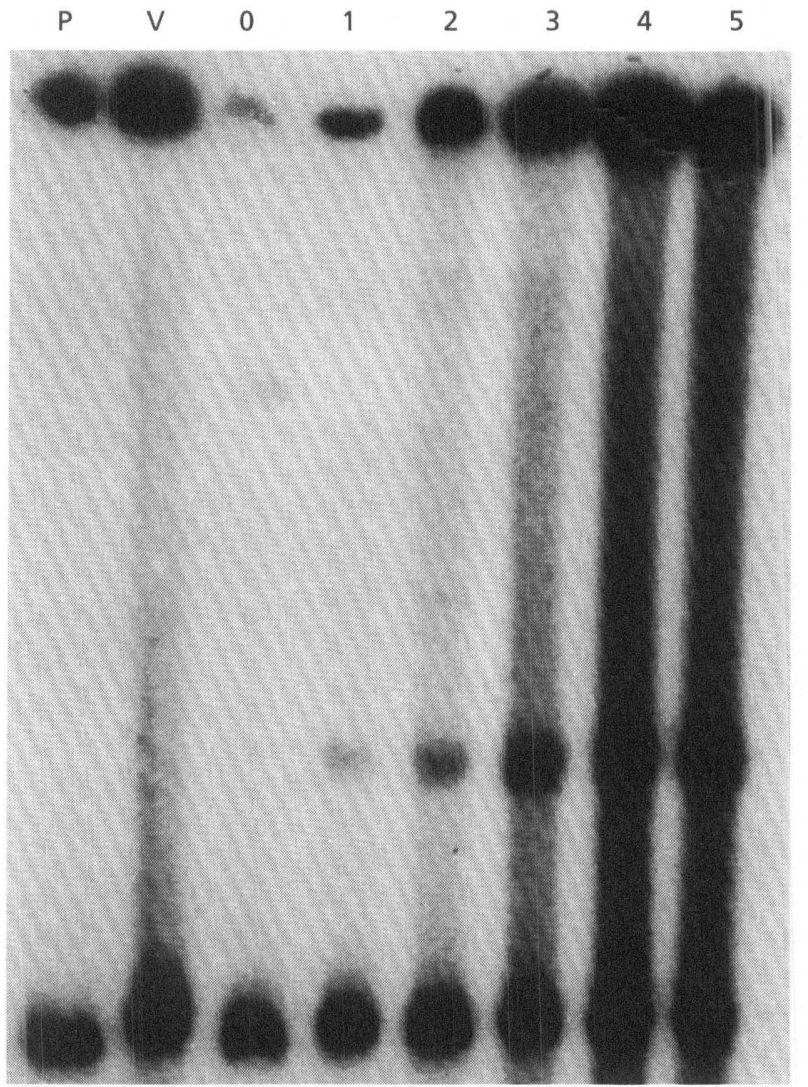

Fig. 3. Mobility shift assay of proteins extracted from cultures at different stages of growth and sporulation with DNA from the spoVA promoter region. A 317 bp DNA fragment extending from -182 to +120 was used as labelled probe. Protein was extracted from vegetative cultures (lane $V$ ) and at various times during sporulation (0, 1, 2, 3, 4 and $5 \mathrm{~h}$ after the start of sporulation) and incubated with $10 \mathrm{ng}$ labelled probe. Fifty nanograms protein was used for each sample, as described in Methods. Lane P contained probe without any protein extract.

protein complex was occurring early in sporulation, it was possible that a mutation at stage 0 would have an effect. Mutations in spoO $A, s p o O B, s p o O F, s p o O H, s p o O J$ and spoOK surprisingly had no effect on formation of the DNA-protein complex (Fig. 4). In the example shown. the retarded band was fainter for the $s p o O F$ and $s p o O H$ mutants. In other experiments the band obtained with these mutants was of comparable intensity to the band obtained with strain MB24. The retarding activity was also present in extracts of spoOE, spoII $A A, s p o I I A C$, spoIIE, spoIIG, spoIIIA, spoIIIC, spoIIIE, spoIIIG and spollIJ mutants (data not shown).

\section{Effect of copy number on expression of spoVA}

The manipulation of gene copy number has been used to analyse the expression of the spoll $A$ (Piggot \& Curtis, 1987) and spoOF loci (Chapman \& Piggot, 1987). To examine further the role of the $5^{\prime}$ region in controlling transcription of $s p o V A$, the region was fused to lac $Z$ in plasmid pPP153. This plasmid replicates autonomously in

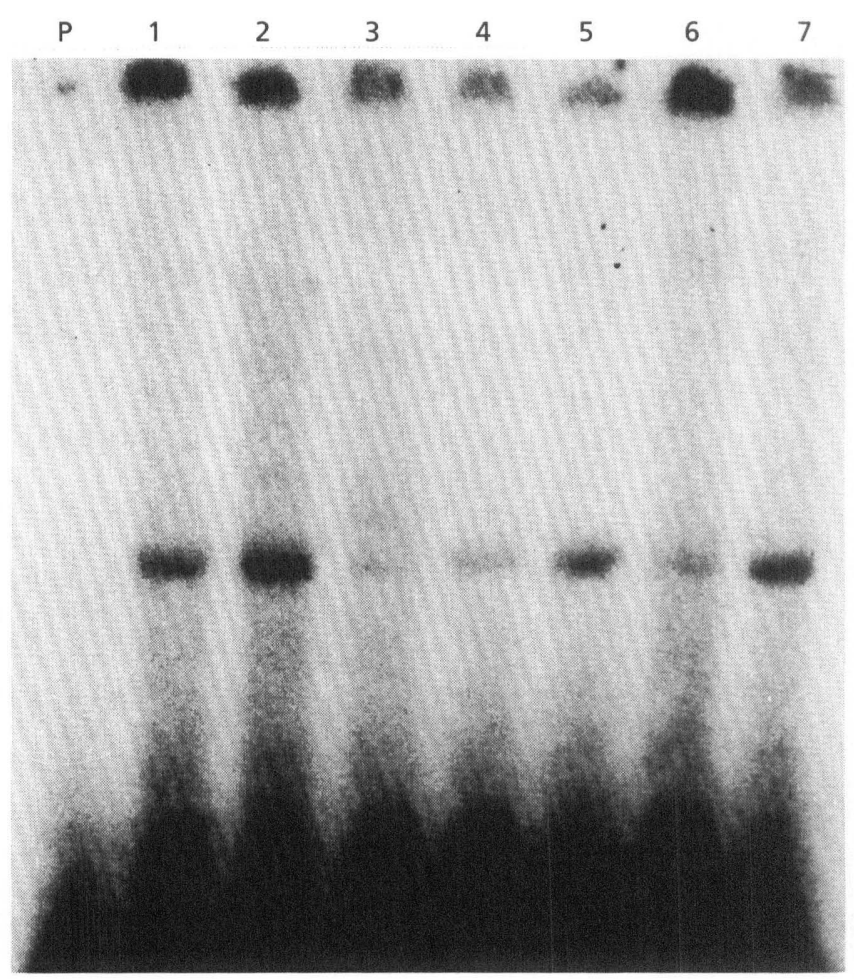

Fig. 4. Mobility shift assay of extracts from strains containing spoO mutations. Protein was extracted from cultures at $1 \mathrm{~h}$ and incubated with $10 \mathrm{ng}$ radiolabelled oligomer. The particular mutations were spoOA34, spoOB136, spoOF221, spoOH17, spoOJ93 and spoOK141 (lanes 1, 2, 3, 4, 5 and 6, respectively). Lane $\mathbf{P}$ contained labelled probe without any protein extract. The extract from the parental spo+ strain MB24 is also shown (lane 7).

E. coli, but is unable to replicate in B. subtilis. Transformants of $B$. subtilis strain MB24 with pPP153 were selected that expressed the plasmid-encoded cat gene. A particular transformant clone was chosen for subsequent study in which the plasmid was shown by Southern blotting to have integrated into the homologous region of the chromosome by a single crossover (data not shown).

Derivatives of $\mathrm{MB} 24$ with tandem repeats of the integrated plasmid pPP153 were selected by growth on media with elevated levels of chloramphenicol. $\beta$-Galactosidase activity during sporulation was determined for strains containing different numbers of tandem repeats (Piggot \& Curtis, 1987). In none of the strains tested was sporulation impaired. Strains having a range of copy numbers began synthesizing $\beta$-galactosidase at about $3 \mathrm{~h}$. The rate of induction was approximately proportional to copy number up to a copy number of 18 (Fig. 5). This indicates that spo $V A$ is not under negative control. When the copy number increased above 18 , enzyme activity did not increase greatly, suggesting that an activator had been titrated out; the data are not precise enough to permit a firm conclusion. We were unable to obtain any strain with a stable copy number above 26 and so were not able to exclude unregulated expression unequivocally. 


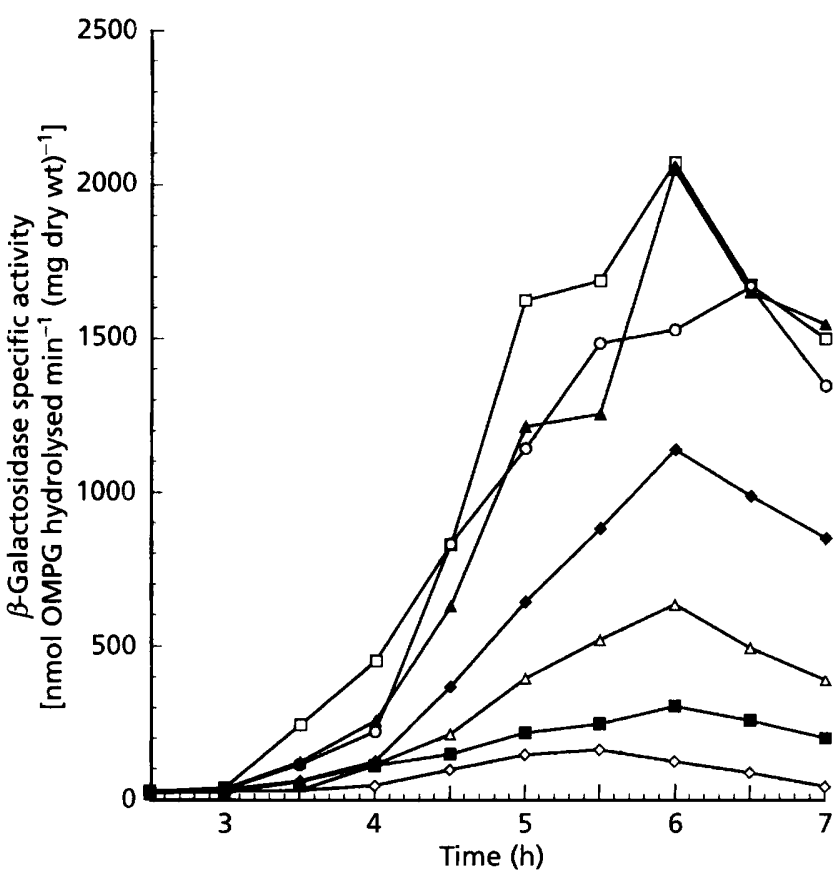

Fig. 5. $\beta$-Galactosidase synthesis during sporulation for $B$. subtilis MB24(pPP153) clones with different numbers of tandem repeats of the integrated plasmid. $\diamond, 1$ copy;, 2 copies; $\triangle, 5$ copies; $\bullet 11$ copies; $\bigcirc, 18$ copies; $\Delta, 21$ copies; $\square, 26$ copies.

\section{DISCUSSION}

The recognition of sequence similarities between $B$. subtilis and $B$. licheniformis made it possible to suggest regions necessary for regulation of the sporulation locus, spoV $A$ (Moldover et al., 1991). Thus, identification of -10 and -35 sequences in $B$. licheniformis that are identical to those shown to be recognized by $\sigma^{\mathrm{G}}$ in $B$. subtilis suggested that transcription of the $B$. licheniformis locus required the $B$. licheniformis homologue of $\sigma^{G}$ (Moldover et al., 1991). The analysis reported here of the homologous region between -45 and -64 , the spoV $A$ box, has revealed another regulatory region for the spoV $A$ locus.

Expression of $\operatorname{spo} V A$ was dependent on the presence of an intact spoV $A$ box. Deletions to -57 (8 bp into this box) or -42 (box removed completely) reduced spoV $A$ expression to less than $15 \%$ of the expression obtained when the upstream region extended to -92 , and deletion to -64 (which removed just $1 \mathrm{bp}$ of the box) reduced expression to $41 \%$ of that of constructs where the box was intact (Fig. 1). Deletion to -69 , which is only $4 \mathrm{bp}$ upstream of this box, had very little effect on expression compared to deletion to -92 . The box region is therefore presumed to be the target of some unknown protein, which regulates spo $V A$ expression. It is important to note that while the level of expression was substantially affected by deletion into the box, the temporal regulation of spo $V A$ appeared not to be affected (Fig. 1).

Deletion of the spo $V A$ box greatly impaired transcription, indicating that the box was the target of an activator. This conclusion was consistent with experiments in which the number of copies of the spoVA $5^{\prime}$ region was selectively amplified. The position of the spo $V A$ box relative to the -35 region of the promoter is also consistent with an activator binding to the box (Collado-Vides $e t$ al., 1991). Too few $\sigma^{G}$ promoters have been characterized to say if the spoV $A$ promoter conforms poorly to the optimal $\sigma^{\mathrm{G}}$ promoter (as might be expected of a promoter under positive control), although spo $V A$ is weakly expressed compared to other genes in the $\sigma^{\mathrm{G}}$ regulon such as $s s p A$, $s s p B$ and $s s p E$. None of the known sequences upstream of loci in the $\sigma^{\mathrm{G}}$ regulon (other than $s p o V A$ ) have a region resembling the spo $V A$ box.

Specific binding of a protein to the spoV $A$ box during sporulation was indicated by mobility shift assays. Binding was not seen during vegetative growth, nor prior to $1 \mathrm{~h}$ of sporulation. The binding was specific to the $20 \mathrm{bp}$ box, but appeared to be stabilized by surrounding sequences, as unlabelled oligonucleotide competed more efficiently with labelled oligonucleotide than with the labelled 310 bp fragment (unpublished observations). We infer that the protein detected by the mobility shift assay is an activator of spoV $A$ transcription.

The binding activity appears about $2 \mathrm{~h}$ prior to transcription of spoVA. Transcription is presumably delayed until the requisite sigma factor, $\sigma^{\mathrm{G}}$ (Nicholson et al., 1989), is active. It is possible that the early appearance of the binding activity relative to spo $V A$ expression indicates a need for the protein elsewhere, and earlier, in sporulation, although we were unable to detect hybridization of the spoV $A$ box to anything other than itself. In any case, the timing suggests that the protein may be present before the sporulation septum is formed, even though it acts on a locus that is expressed only in the forespore.

Of major interest is the pattern of the DNA-protein complex formation in spo mutants. No sporulation mutation tested, including mutations in the $s p o O A, s p o O B$, $s p o O E, s p o O F, s p o O H, s p o O J$ and $s p o O K$ loci which are associated with the start of sporulation, had any effect on formation of the DNA-protein complex. Nor had mutations in two vegetatively expressed loci, spoIIIE and spoIIIJ, that are required for expression of late sporulation genes (Foulger \& Errington, 1989; Errington et al., 1992). These results were unexpected. The presumed activator of spoVA displays temporal regulation, as the binding activity is only detected during sporulation. Thus, the activator, or its binding activity, must be subject to temporal regulation independent of all the known spo loci.

\section{ACKNOWLEDGEMENT}

This work was supported by Public Health Service grant GM43577 from the National Institutes of Health.

\section{REFERENCES}

Ausubel, F. M., Brent, R., Kingston, R. E., Moore, D. D., Seidman, J. G., Smith, J. A. \& Struhl, K. (1990). Current Protocols in Molecular Biology. New York: John Wiley and Sons.

Birnboim, H. C. \& Doly, J. (1979). A rapid alkaline extraction 
procedure for screening recombinant plasmid DNA. Nucleic.4cids Res 7, 1513-1523.

Chapman, J. W. \& Piggot, P. J. (1987). Analysis of the inhibition of sporulation of $B$. subtilis caused by increasing the number of crpies of the spoOF gene. J Gen Microbiol 133, 2079-2088.

Collado-Vides, J., Magasanik, B. \& Gralla, J. D. (1991). Contro site location and transcriptional regulation in Eschericbia coli. Microbiol Rev 55, 371-394.

Errington, J. (1993). Sporulation in Bacillus subtilis: regulation of gene expression and control of morphogenesis. Microbiol Ret 57, $1 \cdots 33$.

Errington, J. \& Mandelstam, J. (1986). Use of a lacZ gene fusion to determine the dependence pattern and the spore compartment expression of sporulation operon spo $V A$ in spo mutants of Bacillus subtilis. J Gen Microbiol 132, 2967-2976.

Errington, J., Appleby, L., Daniel, R. A., Goodfellow, H., Partridge, S. R. \& Yudkin, M. D. (1992). Structure and expression of the spo!IIJ gene of Bacillus subtilis: a vegetatively expressed gene that is essential for $\sigma^{\mathrm{G}}$ activity at an intermediate stage of sporulation. $J$ Gen Microbiol 138, 2609-2618.

Fort, P. \& Errington, J. (1985). Nucleotide sequence and complementation analysis of a polycistronic sporulation operon, spol $A$, in Bacillus subtilis. J Gen Microbiol 131, 1091-1105.

Fort, P. \& Piggot, P. J. (1984). Nucleotide sequence of sporulation locus spoll $A$ in Bacillus subtilis. J Gen Microbiol 30, 2147-2153.

Fouet, A., Jin, S.-F., Raffel, G. \& Sonenshein, A. L. (1990). Multi jle regulatory sites in the Bacillus subtilis citB promoter region. J Bacteriol 172, 5408-5414.

Foulger, D. \& Errington, J. (1989). The role of the sporulation gene spoIIIE in the regulation of prespore-specific gene expression in Bacillus subtilis. Mol Microbiol 3, 1247-1255.

Fried, M. \& Crothers, D. M. (1981). Equilibria and kinetics of !ac repressor-operator interaction by polyacrylamide gel electrophoresis. Nucleic Acids Res 9, 6505-6524.

Henikoff, S. (1984). Unidirection digestion with exonuclease $11 \mathrm{I}$ creates targeted breakpoints for DNA sequencing. Gene 28, 351-369.

Hranueli, D., Piggot, P. J. \& Mandelstam, J. (1974). Statistical estimate of the total number of operons specific for Bacillus subtilis sporulation. J Bacteriol 119, 684-690.

Ish-Horowicz, D. \& Burke, J. F. (1981). Rapid and efficient cosmid cloning. Nucleic Acids Res 9, 2989-2998.

de Lencastre, H. \& Piggot, P. J. (1979). Identification of different sites of expression for spo loci by transformation of Bacillus subtilis. J Gen Microbiol 114, 377-389.
Moldover, B., Piggot, P. J. \& Yudkin, M. D. (1991). Identification of the promoter and the transcriptional start site of the spol $/ A$ operon of Bacillus subtilis and Bacillus licheniformis. J Gen Microbiol 137, 527-531.

Nakatani, Y., Nicholson, W. L., Neitzke, K.-D., Setlow, P. \& Freese, E. (1989). $\sigma^{\mathrm{G}}$ RNA polymerase controls forespore-specific expression of the glucose dehydrogenase operon in Bacillus subtilis. Nucleic Acids Res 17, 999-1017.

Nicholson, W. L., Sun, D., Setlow, B. \& Setlow, P. (1989). Promoter specificity of $\sigma^{\mathrm{G}}$-containing RNA polymerase from sporulating cells of Bacillus subtilis: identification of a group of forespore-specific promoters. J Bacteriol 171, 2708-2718.

Piggot, P. J. \& Coote, J. G. (1976). Genetic aspects of bacterial endospore formation. Bacteriol Rev 40, 908-962.

Piggot, P. J. \& Curtis, C. A. M. (1987). Analysis of the regulation of gene expression during Bacillus subtilis sporulation by manipulation of the copy number of spo-lacZ fusions. J Bacteriol 169, 1260-1266.

Piggot, P. J., Curtis, C. A. M. \& de Lencastre, H. (1984). Use of integrational plasmid vectors to demonstrate the polycistronic nature of a transcriptional unit (spoll $A$ ) required for sporulation of Bacillus subtilis. J Gen Microbiol 130, 2123-2136.

Sanger, F., Nicklen, S. \& Coulson, A. R. (1977). DNA sequencing with chain terminating inhibitors. Proc Natl Acad Sci US.A $\mathbf{7 4}$ 5463-5467.

Stragier, P. (1994). A few good genes: developmental loci in Bacillus subtilis. In Regulation of Bacterial Differentiation, pp. 207-245. Edited by P. J. Piggot, C. P. Moran, Jr \& P. Youngman. Washington, DC: American Society for Microbiology.

Tao, Y. P., Hudspeth, D. S. S. \& Vary, P. S. (1992). Cloning and sequencing of the Bacillus megaterium spoII $A$ operon. Biocbimie 74, 695-704.

Wu, J.-J., Gaukler-Howard, M. \& Piggot, P. J. (1989). Regulation of transcription of the Bacillus subtilis spolI A locus. J Bacteriol 171, 692-698.

Youngman, P., Poth, H., Green, B., York, K., Olmedo, G. \& Smith, K. (1989). Methods for genetic manipulation, cloning, and functional analysis of sporulation genes in Bacillus subtilis. In Regulation of Prokaryotic Development, pp. 65-87. Edited by I. Smith, R. A. Slepecky \& P. Setlow. Washington, DC: American Society for Microbiology.

Zuber, P. \& Losick, R. (1987). Role of AbrB in SpoOA- and SpoOBdependent utilization of a sporulation promoter in Bacillus subtilis. $J$ Bacteriol 169, 2223-2230.

Received 25 March 1994; revised 9 May 1994; accepted 16 May 1994. 